\title{
固定結合部における結合面静摩擦特性の高精度測定装置の開発
}

\author{
稲垣 史彦 ${ }^{* 1, * 2}$, 森田 昇 ${ }^{* 3}$, 比田井 洋史 ${ }^{* 2}$, 松坂 壮太 ${ }^{* 2}$

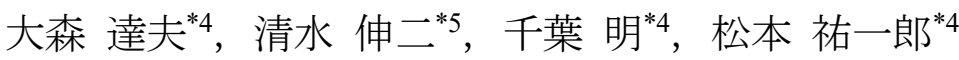

\section{Development of the high precision measurement device of static friction characteristics between surfaces at the fixed coupling section} \author{
Tatsuo OHMORI ${ }^{* 4}$, Shinji SHIMIZU ${ }^{* 5}$, Akira CHIBA ${ }^{* 4}$ and Yuichiro MATSUMOTO ${ }^{* 4}$ \\ ${ }^{* 1}$ Mitsubishi Hitachi Tool Engineering, Ltd. Narita plant \\ 13-2 Shinizumi, Narita-shi, Chiba 286-0825, Japan

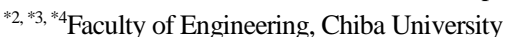 \\ 1-33 Yayoi-cho, Inage-ku, Chiba-shi, Chiba 263-8522, Japan \\ ${ }^{* 5}$ Nippon Institute of Technology \\ 4-1 Gakuendai, Miyashiro-machi, Minami Saitama-gun, Saitama 345-8501, Japan
}

Fumihiko INAGAKI ${ }^{* 1, * 2}$, Noboru MORITA ${ }^{* 3}$, Hirofumi HIDAI ${ }^{* 2}$, Souta MATSUSAKA $^{* 2}$,

Received: 5 July 2019; Revised: 19 August 2019; Accepted: 12 September 2019

\begin{abstract}
Mechanical systems have many joints within. It is well known that the parameters such as contact stiffness, static friction coefficient, kinetic friction coefficient and attenuation coefficient affect static, kinetic, thermal and motion characteristic of them strongly. In these parameters, the static friction coefficient reigns the character of maximum fixing resistance. However, conventional devices cannot be applied to measure the precise static friction coefficient on the coupling surfaces due to their tiny contact surface, unstable loading method and moment force acts on the contact surface. In this paper, we report a novel device we developed for measuring the static friction coefficient between fixed coupling surfaces which solves problems of the conventional devices. The new device enabled stable surface contact and uniform surface pressure by deploying the bearing unit with aligning function at the loading system. In addition, the frictional force applied on the same plane of the contact face of the specimen eliminated moment force. Furthermore, test result shows no component force except the load and frictional force. Moreover, the peak of the frictional force was successfully captured by choosing the proper sampling rate on data logger. Finally, the verification test confirmed that the developed measurement device is able to evaluate the influence of the surface roughness on the static friction coefficient.
\end{abstract}

Keywords : Measurement device, Static friction characteristic, Static friction coefficient, High pressure, Face contact

\section{1. 緒言}

工作機械を代表とする精密機械システムでは，多数の構成要素部品がそれぞれに必要とされる機能に応じた結 合方式で結合されており，非常に多くの結合部が存在している，それら結合部には結合面が存在し，システムの 静特性，動特性，熱特性および運動特性に大きな影響を及ぼしている。そして，これらの特性に大きな影響を及 ぼすパラメータとして，接触剛性，減衰係数，接触熱抵抗，静摩擦係数，動摩擦係数が挙げられる(中村他, 2013,

No.19-00275 [DOI:10.1299/transjsme.19-00275], J-STAGE Advance Publication date : 20 September, 2019

${ }^{* 1}$ 正員，三菱日立ツール(株) 開発技術本部 成田分室（厂286-0825 千葉県成田市新泉 13-2)

*2 正員, 千葉大学 大学院（干263-8522 千葉県千葉市稲毛区弥生町 1-33）

*3 正員, フェロー, 千葉大学 大学院

${ }^{*} 4$ 千葉大学 大学院

*5 正員, フェロー, 日本工業大学（广245-8501＼cjkstart埼玉県南埼玉郡宮代町学園大 4-1）

E-mail of corresponding author: finagaki@mmc-hitachitool.co.jp 
Inagaki, Morita, Hidai, Matsusaka, Ohmori, Shimizu, Chiba and Matsumoto,

Transactions of the JSME (in Japanese), Vol.85, No.878 (2019)

山下他, 2015, 品川, 社本, 2012, 清水, 1998, 伊東, 益子, 1974, 舩橋他, 1986, 狩野他, 1985, 磯野, 古賀, 1982). これ らのうち, 静摩擦係数は全ての特性に影響を及ぼしていると考えられ，これまでに多くの研究がなされている.

例えば，低い面圧における静摩擦係数に関するもの(Jeremic et al., 2013, White and Zei, 1951), 高圧下における静 摩擦係数に関するもの(竹中, 1936, 津村, 高橋, 1951), 摺動部品の初動特性に関するもの，接線方向の変位特性 を明らかにしようとするもの(久門他, 1978, 藤本他, 1997), 微小突起モデルによる静摩擦特性の解明に関するもの (加藤他, 1979, Kogut and Etsion, 2004)など, 多くの評価試験が行われている.

固定結合部において，ずれ動きが生じることは精密機械システムに重大な問題を引き起こすため，接線力に対 して滑りやずれが起こる固定限界特性の把握は大変重要である。しかし，固定結合部における限界抵抗について は, ほとんど評価がなされていない. また, 前述の研究で用いられる実験装置には, 次章で明らかにするように, 結合面圧を付与する荷重負荷機構や, 結合面に対してせん断方向に摩擦力を付与する接線力の負荷機構に問題点 があり，実際の固定結合部に相当する接触状態下での評価を行うことができない，そのため，本研究が目指す， 固定結合部における固定限界特性の評価を目的とした静摩擦係数の高精度測定には不適である.

加えて, 固定結合部の静特性を支配していると考えられる, 結合面の面粗さや面積, 結合面の加工方法, そし て，それらの組み合わせなど，多くのパラメータの影響については殆ど評価されていないのが現状であるそそこ で，本研究では従来装置の問題点を解決し，さらには，これまで検討がなされていないパラメータの組み合わせ を幅広く検討可能な装置を開発する.

\section{2. 従来装置の問題点と課題}

従来の摩擦試験装置を用いて固定結合面における静摩擦係数を測定する場合の問題点として，以下の 3 項目が 挙げられる.

(1) 静摩擦係数測定時の結合面接触状態

図 1 に, 従来研究の接触形態と本装置が対象とする面接触状態の模式図を示寸. 面接触状態での高精度な静摩 擦係数測定は技術的な課題が多く困難である，そのため，ボールオンディスクなど汎用的な摩擦試験機の多くは 接触形態を簡易的に点もしくは線接触とするため, 球と平面もしくは円柱と平面といった形状の試料を用いてい る（掛川他, 2015, Hwang and Gahr, 2003, 渡辺他, 1994, Garc1'a and Martini, 2012)。これらの実験装置で得られる静 摩擦係数は主に摺動部品類の初動を把握するために用いられるが, 点や線といった接触形態は面接触状態におけ る表面粗さやうねりといった要素が静摩擦力におよぼす影響を十分に反映できない.

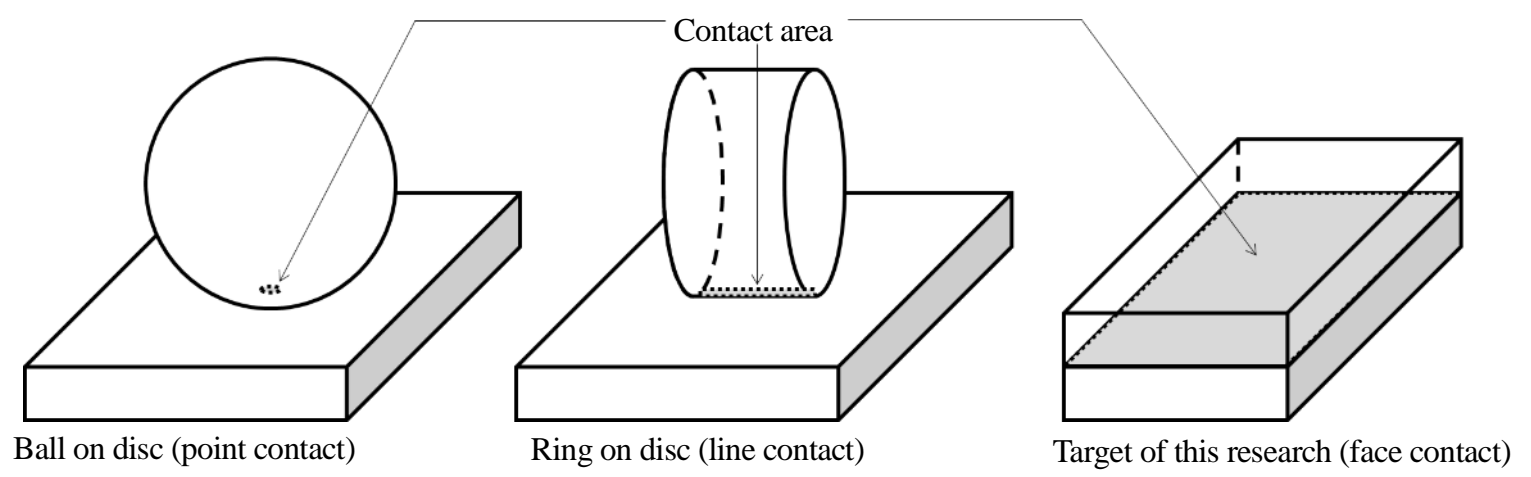

Fig. 1 Combination of the specimen's shape and contact style. 
（2）結合面圧付与のための荷重負荷機構

荷重負荷の方法として, 試料上部に鍾を配置もしくは試料の自重を鍾とする方法が広く採用されている(田中他, 2010, 上村他, 1956). この方法は, 簡便に荷重を負荷でき, 荷重值を把握しやすい一方で, 錘の重心位置や設置位 置次第で垂直成分のほかに水平成分分力が作用する問題がある．この場合，接触面に生じる荷重に偏りが生じる ため，面圧を均一に付与できない，また，搭載できる錘の量には制約が生じるため，観察対象の面積が増加する につれて面圧が低下してしまう。

(3) 最大せん断方向結合力評価のための接線力の負荷機構

図 2 に，荷重，接線力および接触面に作用寸る分力の関係を示す．試料接触面と異なる平面上位置に接線力を 加える場合，接線力とせん断方向の結合力が同一線上にないため，接触面にはモーメントが作用する（Nakamura et al., 2000, 桑村, 2011, Charsetad and Khorsandijou, 2012)。この場合，接線力が接触面に均一に負荷されず，正確な 最大せん断方向結合力が得られない. また，せん断方向結合力の精度評価も行われておらず，今後の課題と言え る.

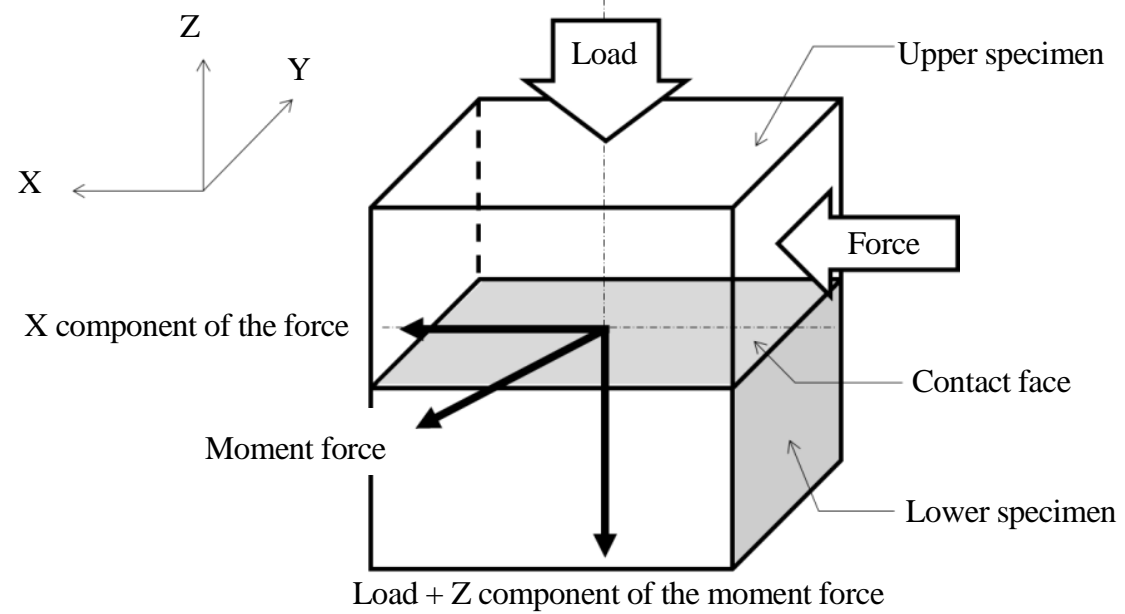

Fig. 2 Positional relation between load, force and moment force effects on contact surface.

\section{3. 新装置の試作}

図 3 に，前述の問題点を解決し，固定結合面間に生じる静摩擦係数を測定できる装置の全体像を示す（三菱日 立ツール株式会社, 2018)。試作に際して，試料は平面の組み合わせとすることで面接触状態とし，寸法は高面圧 を受ける小型部品を想定し直径 $25 \mathrm{~mm}$ の円形状とした．荷重は前述の試料接触面に M16 ねじの軸力が作用した 際の面圧約 60MPa から算出し，30000N に設定している。このとき，本装置の試料接触面積は公称面積で 490.8739 $\mathrm{mm}^{2}$ である. 一方で，点接触となる $\phi 6 \mathrm{~mm}$ のボールオンディスクに同面圧を負荷した際の接触面積をへ ルツの接触応力から算出すると $0.002 \mathrm{~mm}^{2}$ 程度, 線接触となる幅 $6.3 \mathrm{~mm} \phi 35 \mathrm{~mm}$ のリングオンディスクでは 0.038 $\mathrm{mm}^{2}$ 程度と小さく, $0.1 \mathrm{~mm}$ 台の表面粗さやう衫りを評価することができない. なお，これらの計算は鋼製試料を 想定し，ヤング率として $210 \mathrm{GPa}$ ，ポアソン比に 0.3 を用いた。 このことから, 本装置は, 点接触および線接触と なる従来装置に比べて，面粗さや，うねりといったパラメータを広く評価できる．ここで，上部試料と下部試料 の接触面形状寸法は同一としている，これにより，試料結合面に生じる摩擦力のみ評価できる.

なお，高荷重下で安定した測定を行うためには，装置は十分な剛性と精度を有する定盤上に設置することが望 ましい，そこで，本装置はマシニングセンタのテーブル上に設置することにより十分な剛性を確保し，また動作 軸を活用することで装置構成部品の高精度な位置決めを実現した。 


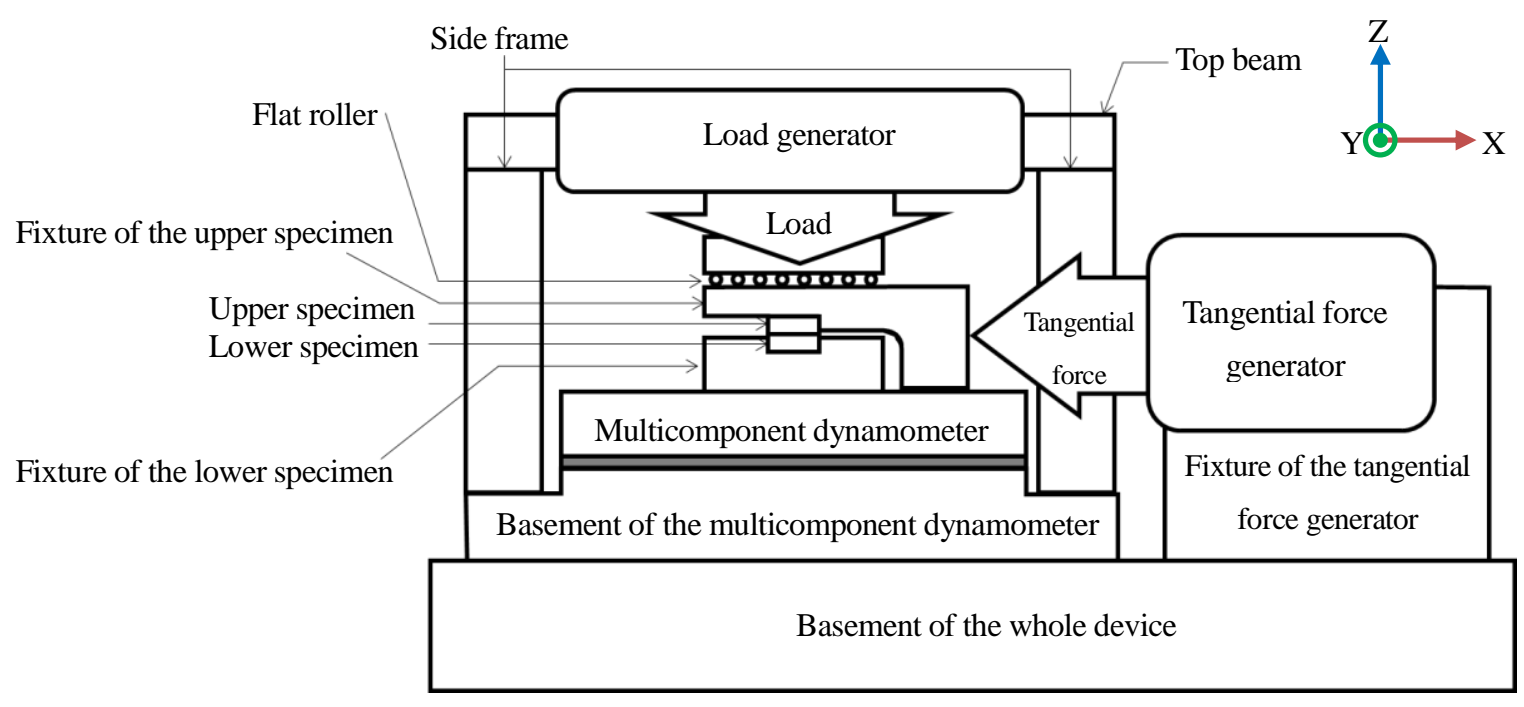

Fig. 3 Schematic diagram of the measurement device of the static friction coefficient between surfaces at the fixed coupling section.

接線力負荷機構にはモータ制御の油圧ユニットを使用し，接触面にモーメントが作用しないよう接触面と同一 平面上に接線力を加えるよう設計した。 また，荷重が負荷された試料に接線力を加える際，荷重負荷機構が接線 力による影響を受けないよう, 荷重負荷機構の下部にはフラットローラを設置している. これにより接線力を負 荷してもモーメント力などが発生せず，所要の荷重が負荷可能となる.

ここで, 荷重負荷機構について検討したモデル模式図を図 4 に示す. (a)ねじのみの場合と，(b)㸚じ端部に鋼球 を介した場合に対して，上下に配置した円柱試料に感圧紙を挟み荷重を $30000 \mathrm{~N}$ まで負荷した。感圧紙は富士フ イルム社製プレスケールを用いた．試料間に挟み込んだ状態で荷重を負荷し，所定の時間待機したあと荷重を除 荷し面圧の分布状態を確認した. 得られた分力值を図 5, 感圧紙の色分布を図 6 に示寸.

結果より，ねじ単体で荷重を負荷した場合には荷重の立ち上がりに乱れが生じるほか，軸力以外の分力の発生 や試料接触面の面圧も偏りが認められる.また鋼球を介寸ることで荷重の立ち上がりは一定に近付いているが， 軸力以外の分力が $1100 \mathrm{~N}$ 程度発生しており接触面の面圧分布にも偏りがある.

図 7 に，これまでの検討を踏まえ製作した装置動作部の詳細を示す。最終的に，本開発装置は荷重負荷機構お よび接線力負荷機構に, ねじ端部の鋼球にくわえて調心座付きスラスト軸受けを配置した.

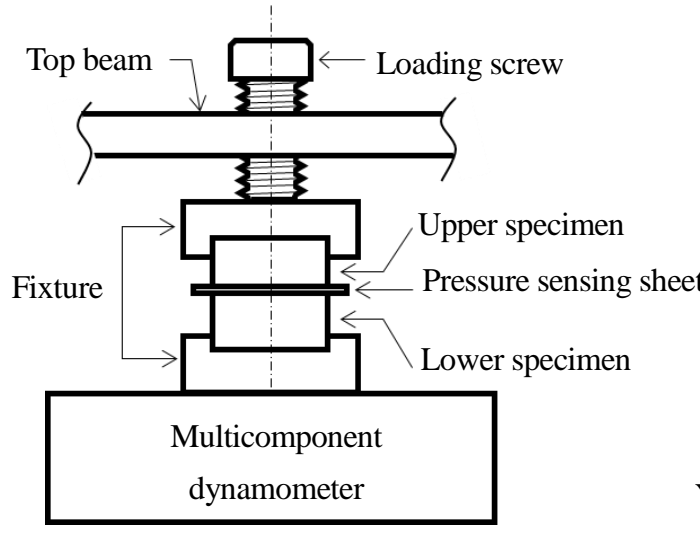

(a) Forced by screw

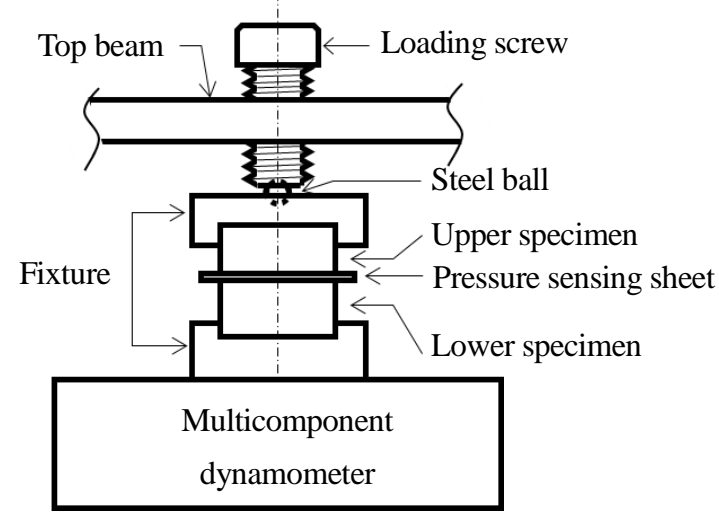

(b) Forced by screw and steel ball

Fig. 4 Schematic diagram of the testing set up of loading methods. 


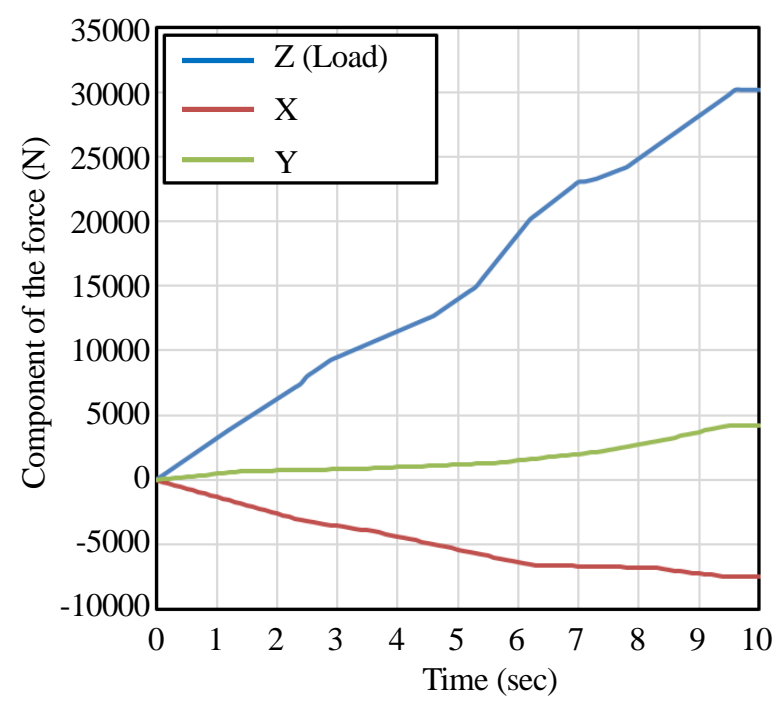

(a) Forced by screw

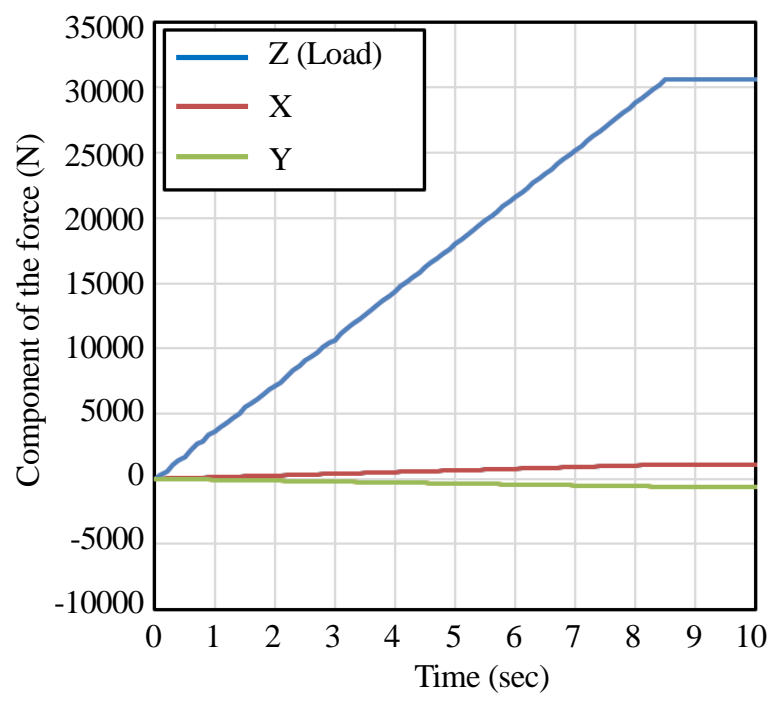

(b) Forced by screw and steel ball

Fig. 5 Relation between loading method and component of the force. Both of the forcing method generated $X$ and $\mathrm{Y}$ component of the force during rise of the load ( $\mathrm{Z}$ component of the force).

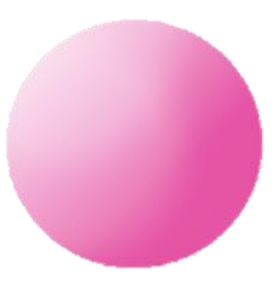

(a) Forced by screw

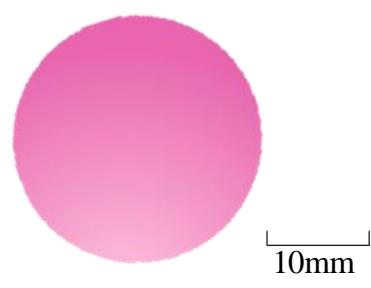

(b) Forced by screw and steel ball

Fig. 6 Distribution of the contact pressure measured by different loading method. Color unevenness appeared on pressure sensing sheet forced by both of the forcing method.

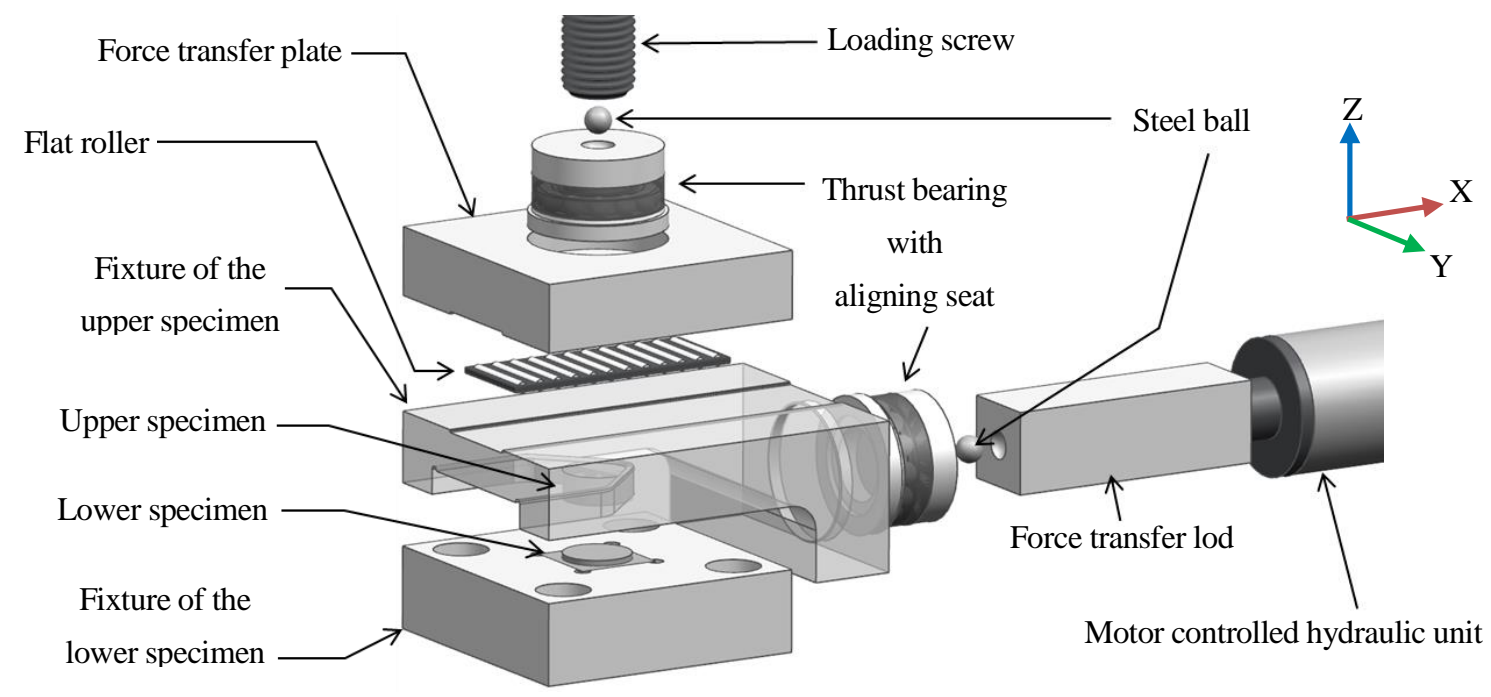

Fig. 7 Detailed view of the functional part of the measurement device. 
Inagaki, Morita, Hidai, Matsusaka, Ohmori, Shimizu, Chiba and Matsumoto,

Transactions of the JSME (in Japanese), Vol.85, No.878 (2019)

\section{4. 新作装置の評価}

\section{$4 \cdot 1$ 評価項目と評価条件}

試作した装置が前述の問題点を解決し, 接触面が全面接触していること, 摩擦力を精度よく評価できることを 確認する. 具体的な内容として, 荷重負荷機構, 接線力負荷位置および分力発生特性の妥当性を評価した. その 後, 接線力測定精度の妥当性, 試料形状寸法が静摩擦係数に及ぼす影響の調査を行い, 最後に開発した装置が表 面粗さの違いにより静摩擦係数の差異が検出できることを実証した.

物性的な安定性と再現性の高さを考慮し，試料材に $45 \mathrm{HRC}$ まで焼き入れ処理を施したダイス鋼(日立金属製 DAC)を選定した．接触面は研削加工にて製作し，接触式形状測定機を用いて試料接触面を放射方向に $120^{\circ}$ 位相 で 3 回測定し，表面のうねりが全体で $0.5 \mu \mathrm{m}$ 未満であることを確認している.

実験に際して, 表面油分を取り除くため試料をアセトン中で 15 分間超音波洗浄し乾燥させた. その後, 接線力 負荷方向に対して, 試料表面の研削筋が直交するように設置した. 荷重負荷後は 30 秒間の静的精度確認時間を設 け，測定機器類の安定性を確認したうえで接線力を約 4000N/sec の一定速度で負荷した．接線力の負荷は，試料 のずれ動きを目視で確認した時点で停止した，静摩擦係数は，最大摩擦力の值を，その際の荷重值で除して求め ている.

\section{$4 \cdot 2$ 評価結果と考察}

\section{$4 \cdot 2 \cdot 1$ 荷重負荷機構の妥当性}

本装置の荷重負荷機構が高荷重を精度よく負荷できることを検証するため, 前章の荷重負荷機構検討と同様の 実験を実施した．各方向分力の測定結果を図 8 に，感圧紙の色分布状態を図 9 に示寸.

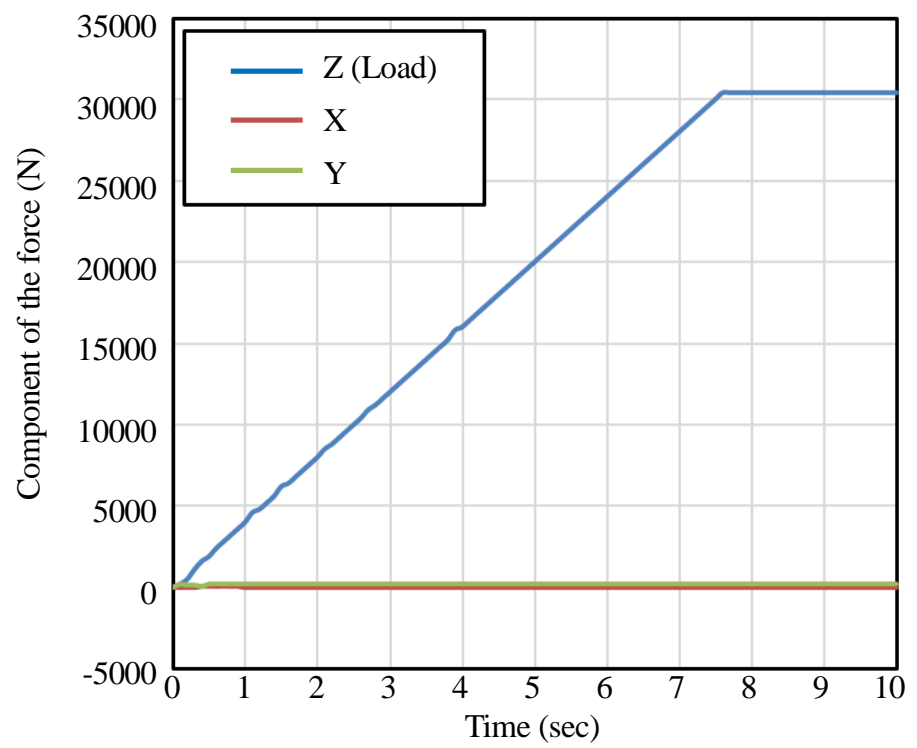

Fig. 8 Relation between time and component of the force. $\mathrm{X}$ and $\mathrm{Y}$ component of the force is less than $0.6 \%$ of the load.

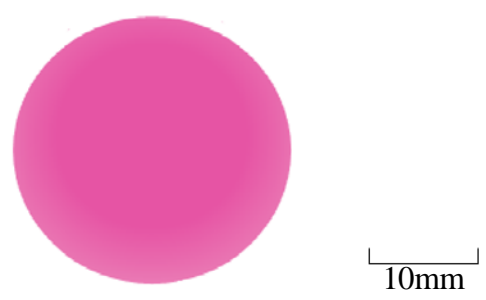

Fig. 9 Distribution of the contact pressure of developed measurement device. Pressure sensing sheet showed uniform color distribution compare to the results of conventional loading method shown in Fig. 6. 
Inagaki, Morita, Hidai, Matsusaka, Ohmori, Shimizu, Chiba and Matsumoto,

Transactions of the JSME (in Japanese), Vol.85, No.878 (2019)

図 8 の結果より, 本装置の荷重負荷機構は平面方向分力の発生が垂直方向分力の $0.6 \%$ 未満であり軸力が正確に 伝達されている. また図 9 の結果より, 試料接触面全体に面圧が均等に分布している. この結果より, 調心座付 きスラスト軸受けは，鋼球とねじおよび治具間に生じていた抵抗を抑えていることが分かる．これらの検証結果 により, 本装置は高面圧を接触面全体に負荷できることが確認された.

\section{$4 \cdot 2 \cdot 2$ 接線力負荷位置の妥当性}

図 10 に接線力負荷位置と静摩擦係数の関係を示す.本装置は接線力が試料接触面に及ぼすモーメントの影響 を除外するため，試料接触面と同一平面上に接線力を負荷している．この妥当性を確認するため，接線力負荷位 置を試料接触面垂直方向に $0 \mathrm{~mm}$ (同一平面上)から $2.0 \mathrm{~mm}$ まで変化させて実験を行った.

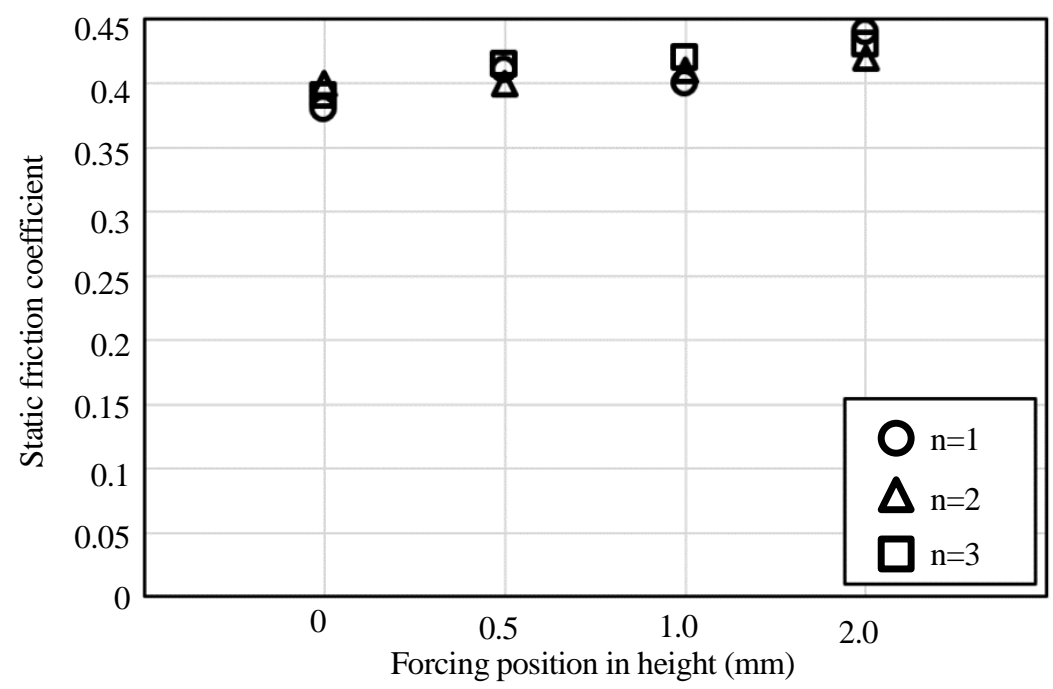

Fig. 10 Relation between forcing position in height and static friction coefficient. Static friction coefficient showed higher value when the forcing position has a gap in height from the contact surface.

この結果より, 接線力負荷位置が試料接触面から垂直方向に離れるほど静摩擦係数值は大きくなる傾向にある. この原因としては接線力のほかにモーメントが接触面に作用し，試料の荷重負荷状態に乱れが生じていることが 考えられる. このことから，試料接触面と同一平面上に接線力を負荷することで，モーメントを抑えられること が確認された。

\section{$4 \cdot 2 \cdot 3$ 接線力測定精度の妥当性}

信頼性の高い静摩擦係数を求めるためには, 荷重と接線力のほかに分力が生じないことが重要である. 高精度 に組上げられた本装置の分力発生特性がこの点を満たすことを検証するため, 接線力の精度を評価した.

図 11 に接線力負荷時の分力を示す，摩擦力であるX 方向分力が増加する間の，Y 方向分力の増加率は $0.2 \%$ 程 度である．これは本開発装置が試料接触面に精度よく接線力を負荷できていることを示している．同時に，荷重 負荷方向の Z 方向分力に関しても，X方向分力の増加にともなって変化することなく一定の值を保っている. ま た摩擦力の微細な挙動や，試料がずれ動く際の最大值を詳細に観察できることが確認された. 


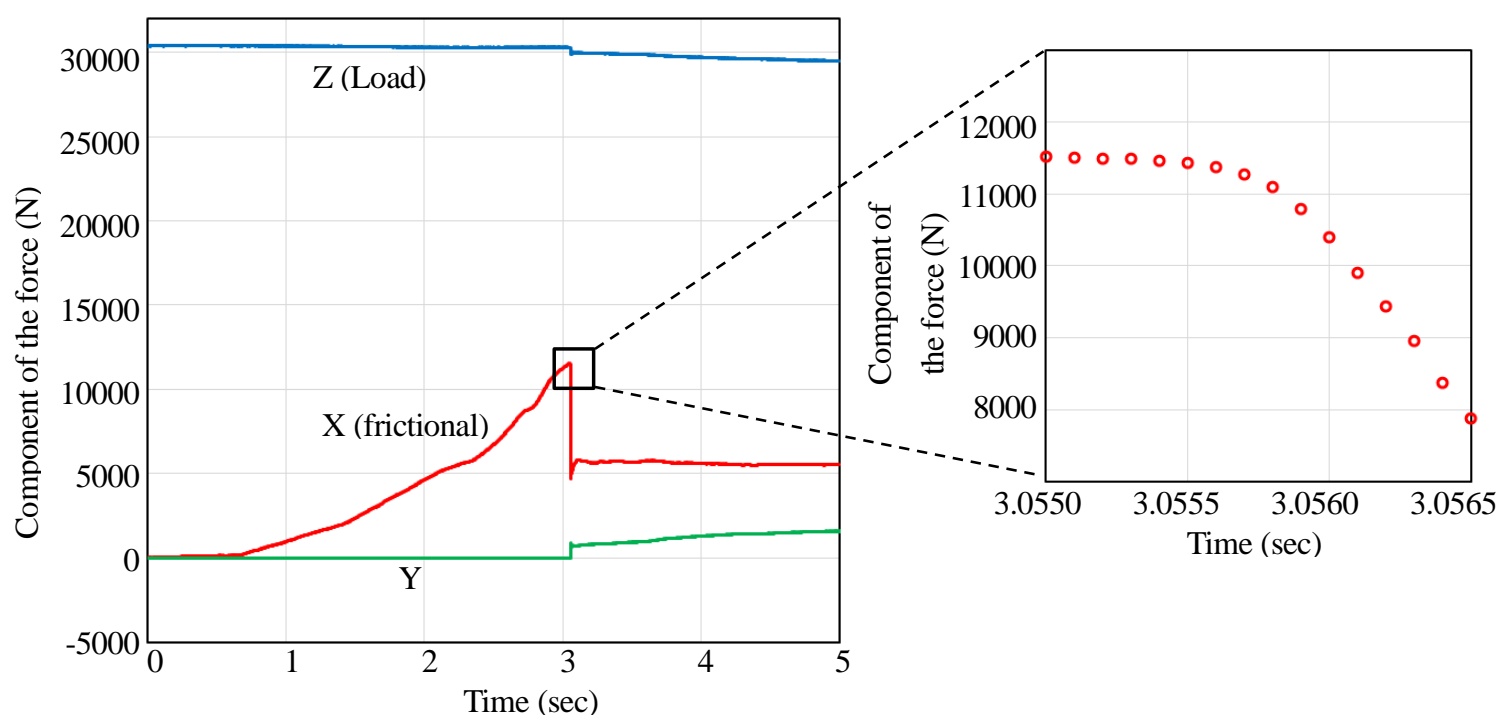

Fig. 11 Exported curve of component's force. Z component force (load) keeps stable value during rise of the $\mathrm{X}$ component force (frictional force). Y component force generated only $0.2 \%$ of the load. Closed up window of the peak of frictional force certifies this device has proper sampling rate to catch the maximum frictional force.

\section{$4 \cdot 2 \cdot 4$ 試料形状寸法が静摩擦係数に及ぼす影響評価}

図 12 に試料接触形態と静摩擦係数の関係を示す. 本装置は試料端部の食い込みを除くため試料の形状寸法を 同一としている．この妥当性を検証するため，(a)直径 $25 \mathrm{~mm}$ 円柱試料どうしの接触(b)直径 $25 \mathrm{~mm}$ 円柱と広い平面 の接触形態にて実験を行った.

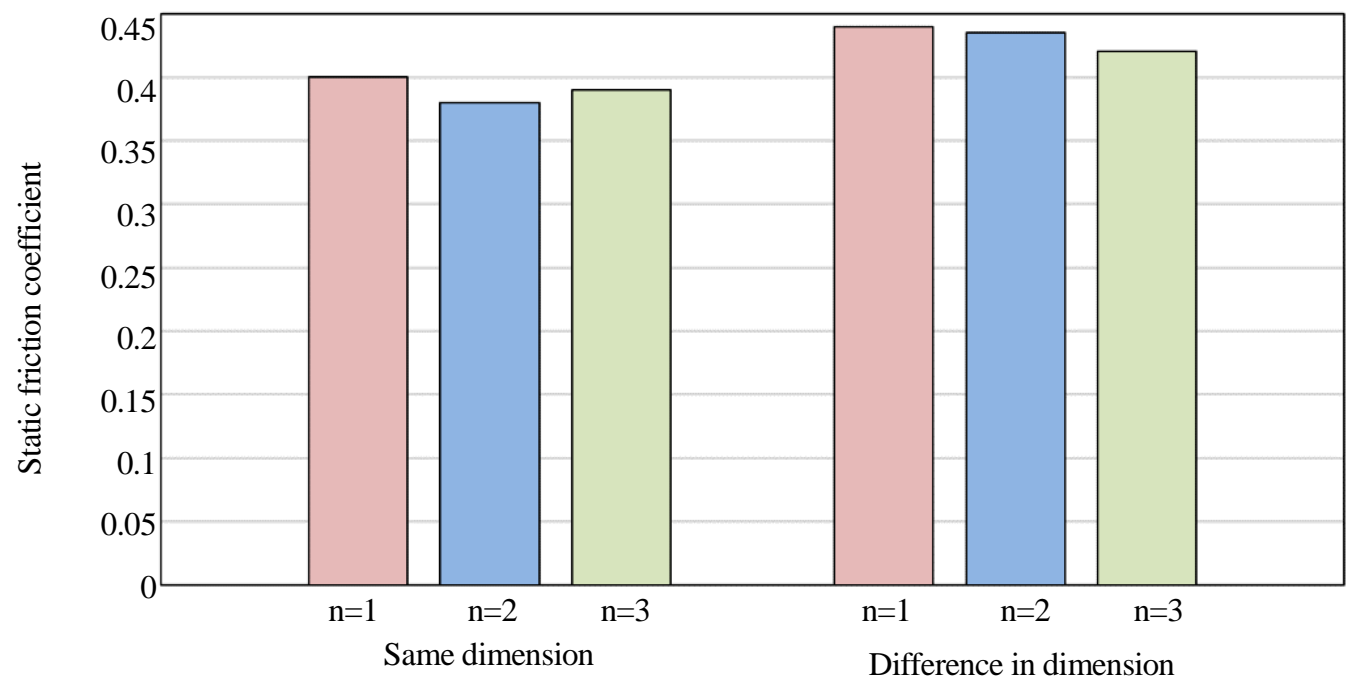

Outline shape of the specimen

Fig. 12 Relation between contact style and static friction coefficient. Combination of the specimen which has different outline shape generated approximately $10 \%$ higher value of static friction coefficient compare to the combination of the same outline shape.

この結果より，試料輪郭形状に差異がある場合の静摩擦係数は 10\%程度大きいことが確認できる.ここで(b)の 平面側試料の接触面端部を観察した結果を図 13 に示寸. 対となる円柱試料によって掘り起こされた痕跡が確認 できる．この検証により，本装置は掘り起こし力の影響を受けず，試料形状寸法を同一とすることで接触面に生 じる摩擦力のみを測定できると考えられる. 


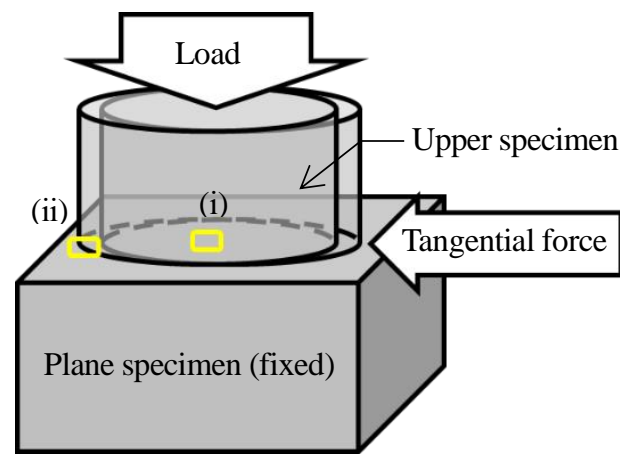

Fig. 13 Surface of the plane specimen after test. Terminus point of the sliding shows dug material which is not appeared at inner part of the contact face along the outline of the upper specimen.

\section{$4 \cdot 2 \cdot 5$ 表面粗さが静摩擦係数におよぼす影響の実証}

これまでの検証により, 本開発装置は固定結合部の結合面に生じる静摩擦係数を測定できることが確認された. 静摩擦力は, 表面粗さに起因する真実接触面積の差異に影響を受けることが解析などにより明らかになっている. そこで，性能評価として，本開発装置が試料表面粗さの影響を静摩擦係数に反映できるか検証する。試料は輪郭

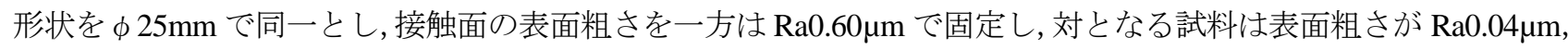
$0.39 \mu \mathrm{m}, 0.60 \mu \mathrm{m}$ の 3 種製作した。試料の平面度がいずれも $0.5 \mu \mathrm{m}$ 未満であることを確認し，検証を実施した.

図 14 に結果を示す。この結果より，各条件における試験結果のばらつきが少なく再現性が高いことがわかる. また試料表面粗さが大きくなるにつれて静摩擦係数值が低下する傾向を明瞭に捉えることができている. この原 因として，本検証に用いた試料は材料および硬度が等しく，平面度が高く圧力分布が均一であることから，表面 が平滑な組み合わせほど真実接触面積が大きく, せん断方向結合力が高まったと考えられる.この結果によって, 本開発装置は表面粗さによる摩擦係数の変化を感度よく捉えられることが実証された.

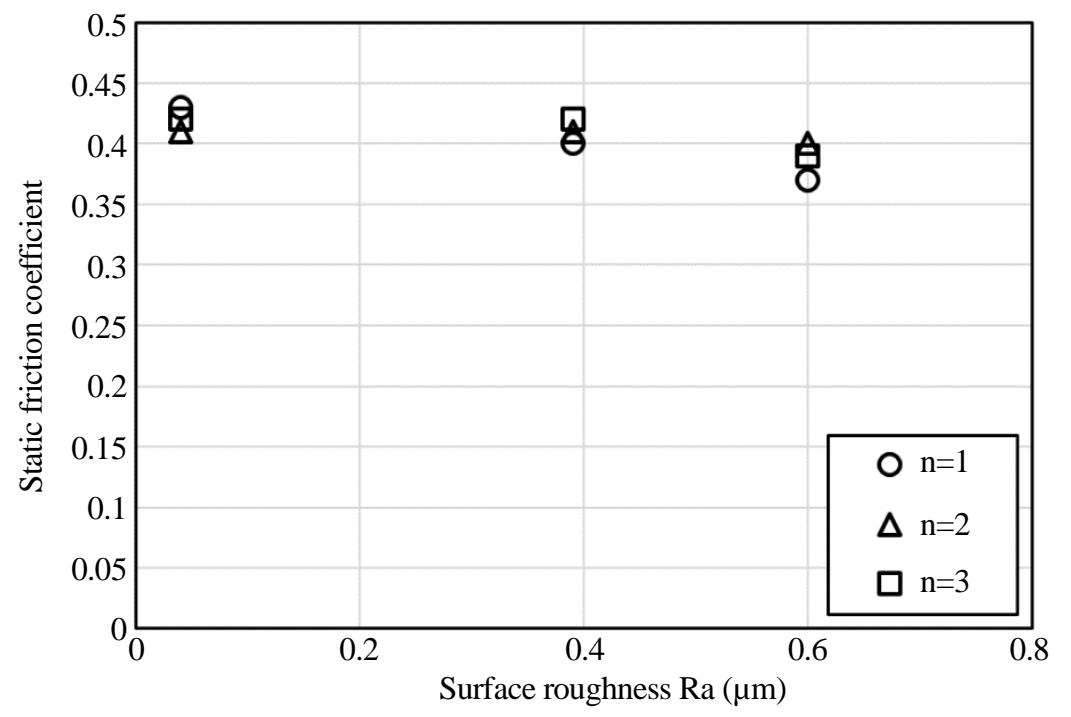

Fig. 14 Relation between surface roughness and static friction coefficient. Tested with the combination of the specimen which has Ra0.6 $\mu \mathrm{m}$ of surface roughness and specimens which has Ra0.04, 0.39 and $0.60 \mu \mathrm{m}$. Combination of $\mathrm{Ra} 0.60$ and $0.04 \mu \mathrm{m}$ showed the highest static friction coefficient 0.42 in average. And the combination of the rougher specimen Ra0.60 and $0.39 \mu \mathrm{m}$ showed lower value 0.41 , then $\mathrm{Ra} 0.60$ and $0.60 \mu \mathrm{m}$ showed 0.38 in average. 
Inagaki, Morita, Hidai, Matsusaka, Ohmori, Shimizu, Chiba and Matsumoto,

Transactions of the JSME (in Japanese), Vol.85, No.878 (2019)

\section{5. 結 言}

固定結合部の結合面における静摩擦係数の測定に関して, 従来の装置が有する問題点を明らかにし，それらを 同時に解決した装置を試作し，その妥当性を評価した．以下に得られた知見を示す．

(1)ねじ，鋼球および調心座付きスラスト軸受けの組み合わせた荷重負荷機構を採用することで，軸力のみを高 荷重域まで負荷でき，試料接触面圧を均一化できる.

(2)接線力負荷位置を試料接触面と同一面上とすることで，モーメントの発生を抑えられる.

(3)試料輪郭形状の差異が静摩擦係数に及ぼす影響の評価を可能にした.

(4)試料表面粗さの差異が静摩擦係数におよぼす影響の評価を可能にした.

\section{文献}

Charsetad, H. and Khorsandijou, S. M., Effect of surface roughness on steel-steel dry friction coefficient, Journal of Mechanical Research and Application, Vol.4, No.3 (2012), pp.45-56.

藤本隆士, 鏡重次郎, 川口尊久, 畑沢鉄三, 吉岡直人, 接線力による接触面間の微小变位特性, トライボロジスト, Vol.42, No.5 (1997), pp.395-402.

舩橋鉀一, 中村隆, 国田忍, 大河内幹義, 馬㴊英二, 組み合わせ接線力による金属接触面の微小変位挙動 ( 1 )一接 触面内突起に方向性が見られない場合一, トライボロジスト, Vol.31, No.10 (1986), pp.729-735.

Garc1'a, J. M. and Martini, A., Measured and predicted static friction for real rough surfaces in point contact, Journal of Tribology, Vol.134 (2012), pp.031501-1-8.

久門輝正, 築添正, 大北高司，接線力を受ける固体接触面の変形機構（第 2 報，圧力分布と潤滑膜の影響），日本 機械学会論文集, Vol.44, No.386 (1978), pp.3575-3583.

Hwang, D. H. and Gahr, K. H., Transition from static to kinetic friction of unlubricated or oil lubricated steel/steel, steel/ceramic and ceramic/ceramic pairs, Wear, Vol.255 (2003), pp.365-375.

磯野宏秋，古賀一夫，衝撃をうける接触面のすべり摩擦（第 1 法），精密機械, Vol.48, No.2 (1982), pp.224-230.

伊東誼, 益子正巳，ボルト結合部の減衰能に関寸る研究(第2 報, 結合面状態の影響)，日本機械学会論文集, Vol.40, No.335 (1974), pp.2058-2065.

Jeremic, B., Vukelicb, D., Todorovica, P. M., Macuzica, I., Pantica, M., Dzunica, D. and Tadica, B., Static friction at high contact temperatures and low contact pressure, Journal of Friction and Wear, Vol.34, No.2 (2013), pp. 114-119.

掛川泰, 清水徹英, 鷺坂芳弘, 楊明, マイクロ金型の表面テクスチャリングとそのドライ摩擦・摩耗挙動のその場 観察, 日本塑性加工学会誌, Vol.56, No.567 (2015), pp.891-896.

狩野正樹, 角張毅, 山田昭夫, 西尾哲也, 結合部における接線方向の剛性と消散エネルギ, 日本機械学論文集 C 編, Vol.51, No.463 (1985), pp.606-615.

加藤仁, 丸井悦男, 小林明発, 松林恒雄, きさげ仕上げ案内面の静摩擦特性について, 日本機械学会論文集 C 編, Vol.45, No.489 (1979), pp.108-117.

Kogut, L. and Etsion, I., A Static friction model for elastic-plastic contacting rough surfaces, Journal of Tribology, Vol.126 (2004), pp.34-40.

桑村仁, 高接触圧における木材と鋼材の摩擦係数 -鉄骨木質構造の研究 その 9-, 日本建築学会構造系論文集, Vol.76, No.666 (2011), pp.1469-1478.

三菱日立ツール株式会社, 摩擦試験装置及び摩擦試験方法, 特願 2018-160973 (2018).

中村恭子, 吉谷明敏, 清水伸二, 坂本治久, 結合部接触剛性の汎用的な同定法の提案, 日本機械学会論文集 C 編, Vol.79, No.807 (2013), pp.4389-4399.

Nakamura, T., Tanaka, S., Hayakawa, K. and Fukai, Y., A Study of the lubrication behavior of solid lubricants in the upsetting process, Journal of Tribology, Vol.122 (2000), pp.803-808.

清水信行, 日本機械学会編, 振動のダンピング技術 (1998), pp.191-193, 養賢堂.

品川幹, 社本英二, 機械構造の結合部における摩擦減衰の解明と定量的予測（ねじり振動が作用する場合），日本 機械学会論文集 C 編, Vol.78, No.790 (2012), pp.2048-2063.

竹中次郎, 高圧力における鋼板の摩擦係数, 機械学会論文集, Vol.2, No.6 (1936), pp.148-150.

田中隆太郎, 井上豪, 細井晃, 上田隆司, 古本達明, レーザ処理と切削の複合加工による創生面の摩擦特性（静止 摩擦特性へおよぼす影響)，日本機械学会論文集 C 編, Vol.76, No.764 (2010), pp.794-799.

津村利光, 高橋敏雄, 高圧力下における摩擦係数, 日本機械学会論文集, Vol.17, No.57 (1951), pp.136-140. 
Inagaki, Morita, Hidai, Matsusaka, Ohmori, Shimizu, Chiba and Matsumoto,

Transactions of the JSME (in Japanese), Vol.85, No.878 (2019)

上村欣一，加賀美幾三，古賀正三，静摩擦現象の微細構造，応用物理, Vol.25, No.1 (1956), pp.34-37.

渡辺茂, 鈴木雅史, 吉村昇, 藤田博之, シリコンウェー八間の静摩擦特性に対する温度の影響, 電気学会論文誌 $\mathrm{A}$ （基礎・材料・共通部門誌）, Vol.114-A, No.2 (1994), pp.168-172.

White, H. S. and Zei, D., Static friction tests with various metal combinations and special lubricants, Journal of Research of the National Bureau of Standards, Vol.46, No.4 (1951), pp.292-298.

山下健一, 清水伸二, 坂本治久, 金属結合面間の動特性測定・評価装置の設計試作，日本機械学会論文集，Vol.81， No.824 (2015), DOI:10.1299/transjsme.14-00517.

\section{References}

Charsetad, H. and Khorsandijou, S. M., Effect of surface roughness on steel-steel dry friction coefficient, Journal of Mechanical Research and Application, Vol.4, No.3 (2012), pp.45-56.

Fujimoto, T., Kagami, J., Kawaguchi, T., Hatakezawa, T. and Yoshioka, N., Micro-displacement characteristics under tangential force between surfaces in contact, Journal of Japanese Society of Tribologists, Vol.42, No.5 (1997), pp.395-402 (in Japanese).

Funabashi, K., Nakamura, T., Kunita, S., Okouchi, M. and Mabuchi, E., Micro-displacement in metal contact caused by cumulative tangential force(1) -In case of contact surface having isotropic topography-, Journal of Japanese Society of Tribologists, Vol.31, No.10 (1986), pp.729-735 (in Japanese).

Garc1'a, J. M. and Martini, A., Measured and predicted static friction for real rough surfaces in point contact, Journal of Tribology, Vol.134 (2012), pp.031501-1-8.

Hisakado,T., Tsukizoe, T. and Ohkita, T., Deformation mechanism of solid interfaces subjected to tangential loads (2nd report, effects of distribution of contact pressure and lubricating film), Transactions of the Japan Society of Mechanical Engineers, Vol.44, No.386 (1978), pp.3575-3583 (in Japanese).

Hwang, D. H. and Gahr, K. H., Transition from static to kinetic friction of unlubricated or oil lubricated steel/steel, steel/ceramic and ceramic/ceramic pairs, Wear, Vol.255 (2003), pp.365-375.

Isono, H. and Koga, K., Friction on interfaces subjected to tangential impact (1st report), Journal of the Japan Society of Precision Engineering, Vol.48, No.2 (1982), pp.224-230 (in Japanese).

Ito, Y. and Masuko, M., Study on the damping capacity of bolted joints (2nd report, effects of the joint surfaces conditions), Transactions of the Japan Society of Mechanical Engineers, Vol.40, No.335 (1974), pp.2058-2065 (in Japanese).

Jeremic, B., Vukelicb, D., Todorovica, P. M., Macuzica, I., Pantica, M., Dzunica, D. and Tadica, B., Static friction at high contact temperatures and low contact pressure, Journal of Friction and Wear, Vol.34, No.2 (2013), pp. 114-119.

Kakegawa, T., Shimizu, T., Sagisaka, Y. and Yang, M., Surface texturing on micro-die and in-situ observation of its dry friction and wear behavior, Journal of JSTP, Vol.56, No.567 (2015), pp.891-896 (in Japanese).

Kano, M., Kakubari, T., Yamada, A. and Nishio T., The tangential stiffness and energyloss of fixing element, Transactions of the Japan Society of Mechanical Engineers, Series C, Vol.51, No.463 (1985), pp.606-615 (in Japanese).

Kato, S., Marui, E., Kobayashi, A. and Matsubayashi, T., Characteristics of static friction of scraped surface slideway, Transactions of the Japan Society of Mechanical Engineers, Series C, Vol.45, No.489 (1979), pp.108-117 (in Japanese).

Kogut, L. and Etsion, I., A static friction model for elastic-plastic contacting rough surfaces, Journal of Tribology, Vol.126 (2004), pp.34-40.

Kuwamura, H., Coefficient of friction between wood and steel under heavy contact, Journal of Structural and Construction Engineering, Vol.76, No.666 (2011), pp.1469-1478 (in Japanese).

Mitsubishi Hitachi Tool Engineering, Ltd., Measurement device and method of the friction coefficient, Japanese Patent Application No. 2018-160973 (2018).

Nakamura, K., Yoshitani, A., Shimizu, S. and Sakamoto, H., Proposition of high accuracy identification method of contact stiffness of joint, Transactions of the Japan Society of Mechanical Engineers, Series C, Vol.79, No.807 (2013), pp.43894399 (in Japanese).

Nakamura, T., Tanaka, S., Hayakawa, K. and Fukai, Y., A study of the lubrication behavior of solid lubricants in the upsetting process, Journal of Tribology, Vol.122 (2000), pp.803-808.

Shimizu, N., edited by JSME, Vibration damping technology (1998), pp.191-193, Yokendou (in Japanese).

Shinagawa, M. and Shamoto, E., Clarification and quantitative prediction of friction damping on contact surface of mechanical structure (case of torsional vibration), Transactions of the Japan Society of Mechanical Engineers, Series C, Vol.78, No.790 
(2012), pp.2048-2063 (in Japanese).

Takenaka, J., Frictional coefficient of steel plate under higher normal pressure, Transactions of the Japan Society of Mechanical Engineers, Vol.2, No.6 (1936), pp.148-150 (in Japanese).

Tanaka, R., Inoue, T., Hosokawa, A., Ueda, T. and Furumoto, T., Frictional characteristics of the surface formed by machining combined with laser heat treatment, Transactions of the Japan Society of Mechanical Engineers, Series C, Vol.76, No.764 (2010), pp.794-799 (in Japanese).

Tsumura, T. and Takahashi, T., Measurement of coefficients of friction under high pressure, Transactions of the Japan Society of Mechanical Engineers, Vol.17, No.57 (1951), pp.136-140 (in Japanese).

Uemura, K., Kagami, I. and Koga, S., The fine structure of static friction, Japanese Journal of Applied Physics, Vol. 25, No.1 (1956), pp.34-37 (in Japanese).

Watanabe, S., Suzuki, M., Yoshimura, N. and Fujita, H., Effect of temperature on static friction characteristics for silicon wafer/silicon wafer contact, T.IEE Japan, Vol.114-A, No.2 (1994), pp.168-172 (in Japanese).

White, H. S. and Zei, D., Static friction tests with various metal combinations and special lubricants, Journal of Research of the National Bureau of Standards, Vol.46, No.4 (1951), pp.292-298.

Yamashita, K., Shimizu, S. and Sakamoto, H., Design and manufacture of testing measurement and evaluation device for dynamic property of metallic interfaces, Transactions of the JSME (in Japanese), Vol.81, No.824 (2015), DOI:10.1299/transjsme.14-00517. 